\title{
IMPLEMENTASI EKSTRAKURIKULER ATLETIK NOMOR LOMPAT JAUH PADA SEKOLAH MENENGAH PERTAMA NEGERI KOTA BENGKULU
}

\author{
Willi Arianto \\ S-1 Pendidikan Jasmani, Universitas Bengkulu, email : willi_arianto@yahoo.com \\ Yarmani \\ Universitas Bengkulu \\ Aliman \\ Universitas Bengkulu
}

\begin{abstract}
Abstrak
Penelitian ini bertujuan untuk mengetahui implementasi ekstrakurikuler atletik nomor lompat jauh pada sekolah menengah pertama negeri kota Bengkulu. Jenis penelitian ini adalah deskriptif kualitatif. Subjek penelitian adalah 3 pembina, 3 pelatih, dan 58 siswa ekstrakurikuler atletik sekolah menengah pertama negeri kota Bengkulu. Teknik pengumpulan data yang digunakan adalah dengan pengamatan (observasi), angket (kuesioner), wawancara, dan dokumentasi. Instrumen yang digunakan adalah wawancara bebas dan angket meggunakan skala likert. Hasil penelitian ini diambil dari hasil angket dari siswa ekstrakurikuler atletik berjumlah 58 siswa, maka di peroleh hasil angket kategori Manajemen Sebesar 58\%, Sarana dan Prasarana 59,41\%, Pelatih yang Kompeten 70,03\%, Motivasi 64,58\%, dan Prestasi sebesar 42,2\%,dan dari semua hasil angket diperoleh rata-rata sebesar 58,84\%. Dan berada pada klasifikasi $40-60 \%$ dalam kategori kurang baik. Sehingga dapat disimpulkan bahwa implementasi ekstrakurikuler atletik nomor lompat jauh pada sekolah menengah pertama negeri kota Bengkulu belum maksimal.
\end{abstract}

Kata Kunci: Implementasi, Ekstrakurikuler, Atletik, Lompat Jauh

\begin{abstract}
This study aims to determine the implemention of extracurricular athletic long jump numbers in the junior high school of the city of Bengkulu. This type of research is qualitative descriptive. The subjects of the study were 3 coaches, 3 trainers and 58 athletic ekstracurricular stundents at the Bengkulu city junior high school. Data collection techniques used are observation, questionnaire, interview, documentation. The instruments used were free intervies and questionnaires using a likert scale. The results of this study were taken from the result of questionnaires from athletic extracurricular stundents totaling 58 stundents, then the result of the management category questionnaire were 58\%, facilities and infrastructure $59.41 \%$, competent coach $70,03 \%$, motivation $64.58 \%$, and achievements. and from all questionnaire results obtained an average of $58,84 \%$. And is in a classification of $40-60 \%$ in the bad category. So that it can be concluded that the implementation of extracurricular athletics in the long jump number in the junior high school of the city of Bengkulu is not maximal.
\end{abstract}

Keywords: Implementasion, Extracurricular, Athletic, Long Jump 


\section{PENDAHULUAN}

Olahraga adalah sebagai salah satu aktifitas fisik maupun psikis seseorang yang berguna untuk menjaga dan meningkatkan kualitas kesehatan seseorang. Berolahraga juga dapat membantu manusia melindungi dari penyakit seperti stroke, jantung, diabetes, tekanan darah tinggi, obesitas, osteoporosis, nyeri punggung, dan dapat meningkatkan suasana hati dan mengurangi stress. Selain manfaat yang telah disebutkan di atas, olahraga juga berperan dalam peningkatan prestasi di sekolah. Dengan implementasi yang sesuai kebutuhan dan kemampuan.

Menurut peraturan menteri pendidikan dan kebudayaan Republik Indonesia nomor 62 tahun 2014 tentang kegiatan ekstrakurikuler pada pendidikan dasar dan pendidikan menengah. Pasal 1 nomor 1dimaksud dengan: kegiatan ekstrakurikuler adalah kegiatan kurikuler yang dilakukan oleh peserta didik di luar jam belajar kegiatan intrakurikuler dan kegiatan kokurikuler. Dan pasal 2 yang dimaksud dengan: kegiatan ekstrakurikuler diselenggarakan dengan tujuan untuk mengembangkan potensi, bakat, minat, kemampuan, kepribadian, kerjasama, dan kemandirian peserta didik secara optimal dalam rangka mendukung pencapaian tujuan dari pendidikan nasional yang telah dirancang.

Peran pelatih sangat berperan dalam peningkatan hasil dari prestasi siswa ektrakurikuler atletik nomor lompat jauh. Peran pelatih terhadap cabang olahraga atletik nomor lompat jauh juga merupakan unsur yang cukup penting karena program latihan yang baik akan dapat meningkatkan gairah para siswa dalam mengikuti kegiatan ekstrakurikuler atletik nomor lompat jauh. Dengan demikian wawasan siswa terhadap atletik nomor lompat jauh semakin luas dan bisa bermanfaat bagi dirinya sendiri maupun orang lain. Selain peran pelatih dan metode latihan yang baik, dalam peningkatan prestasi harus membutuhkan manajemen serta pengelolaan ekstrakurikuler yang baik. Sehingga penerapan yang telah direncanakan akan berjalan sesuai dengan apa yang ingin dicapai.

Berdasarkan kajian pada latar belakang masalah di atas, maka dapat di rumuskan beberapa permasalahan dalam penelitian ini antara lain:

1. Bagaimana

penerapan ekstrakurikuler atletik nomor lompat jauh pada sekolah menengah pertama negeri Kota Bengkulu.

2. Kondisi sarana dan prasarana dalam pelaksanaan kegiatan ekstrakulikuler atletik nomor lompat jauh pada sekolah menengah pertama negeri Kota Bengkulu.

3. Belum jelasnya manajemen pengolaan sumber pelatih.

4. Belum maksimalnya penerapan metode latihan ekstrakurikuler atletik nomor lompat jauh.

5. Minimnya pertandingan atletik nomor lompat jauh tingkat sekolah menengah pertama negeri kota Bengkulu.

6. Pencapaian hasil yang belum maksimal dalam pertandingan atletik nomor lompat jauh tingkat sekolah menengah pertama negeri kota.

7. Belum jelasnya pembinaan ekstrakurikuler atletik nomor 
lompat jauh pada sekolah menengah pertama negeri kota Bengkulu.

Peneliti melakukan observasi ke sekolah-sekolah yang ada di sekolah menengah pertama negeri Kota Bengkulu. Untuk melihat bagaimana penerapan kegiatan ekstrakurikuler yang diterapkan oleh guru atau pelatih ekstrakurikuler atletik tersebut. Sarana dan prasarana yang tersediapun tidak luput dari pengamatan peneliti. Kemudian peneliti melihat juga dari segi kelengkapan sarana dan prasarana serta peran pelatih dan metode latihan sudah dapat di kategorikan baik ataukah belum. Latar belakang ini sendiri peneliti buat berdasarkan observasi.

Implementasi adalah bermuara pada aktivitas, aksi, tindakan atau adanya mekanisme suatu sistem, implementasi bukan sekedar aktivitas, tetapi suatu kegiatan yang terencana dan untuk mencapai tujuan kegiatan. Dari pendapat di atas jelas bahwa implementasi bermuara pada mekanisme suatu sistem. Pengertian mekanisme disini mengandung arti bahwa implementasi bukanlah merupakan sekedar aktivitas, tetapi lebih menekankan pada suatu kegiatan yang matang dan sungguh-sungguh berdasarkan acuan norma tertentu untuk mencapai tujuan kegiatan. Sedangkan menurut kamus besar bahasa Indonesia, pengertian implementasi yaitu melaksanakan dan menerapkan. Pendapat lain dikemukakan juga oleh harsono dalam Fithriani (2002:67) implementasi adalah suatu proses untuk melaksanakan kegiatan menjadi tindakan serta kebijakan dari pengembangan suatu kebijakan dalam rangka penyempurnaan suatu program.

implementasi adalah perluasan aktivitas yang saling menyesuaikan proses interaksi antara tujuan dan tindakan untuk mencapainya serta memerlukan jaringan pelaksana, birokrasi yang efektif. Serta membutuhkan pelaksanaan dan penerapan yang konsisten dalam hal yang sudah dirancang dan diterapkan di lapangan. Sehingga tercapai hal yang diinginkan. (Setiawan, 2004:39)

kegiatan ekstrakulikuler dapat diartikan sebagai kegiatan pendidikan yang dilakukan di luar jam mata pelajaran tatap muka. Kegiatan tersebut dilaksanakan di dalam dan atau di luar lingkungan sekolah untuk memperluas pengetahuan, meningkatkan keterampilan, dan menginternalisasi nilai-nilai atau aturan-aturan agama serta normanorma social, Dengan kata lain, ekstrakulikuler merupakan kegiatan pendidikan di luar jam pelajaran yang ditunjukan untuk membantu perkembangan peserta didik, sesuai dengan kebutuhan, potensi, bakat, dan minat mereka melalui kegiatan yang secara khusus diselenggarakan oleh pendidik dan atau tenaga kependidikan yang berkemampuan dan berkewenangan di sekolah. Menurut Wiyani dalam Deri hanggara (2013:108).

ekstrakulikuler adalah kegiatankegiatan siswa di luar jam pelajaran yang dilaksanakan di sekolah atau di luar sekolah, dengan tujuan untuk memperluas pengetahuan, memahami keterkaitan antar berbagai mata pelajaran, penyaluran bakat dan minat, dan dalam rangka usaha untuk meningkatkan kualitas keimanan dan 
ketakwaan para siswa terhadap tuhan yang maha esa, kesadaran berbangsa dan bernegara, berbudi pekerti luhur, dan sebagainya, wahjosumidjo dalam Kompri (2015:225).

Atletik adalah sekumpulan olahraga yang meliputi lari, jalan, lempar, dan lompat, yang telah menjadi aktifitas olahraga tertua dalam peradapan manusia olahraga ini, dalam budaya inggris dan beberapa Negara lain, dikenal dengan istilah track and field, yang artinya lintasan dan lapangan. (winendra adi, 2008:4). Sedangkan Menurut Winendra adi, dkk. (2008:4). Atletik (athletics) adalah sekumpulan olahraga yang meliputi Lari, jalan, lempar, dan lompat, yang telah menjadi aktivitas olahraga tertua dalam peradapan manusia olahraga ini, dalam budaya inggris dan beberapa Negara lain, dikenal dengan istilah track and field, yang artinya lintasan dan lapangan'.

Menurut Wiri wiarto (2013:32). Lompat jauh adalah suatu bentuk gerakan melompat yang diawali dengan gerakan horizontal dan diubah ke gerakan vertikal dengan jalan melakukan tolakan pada satu kaki yang terkuat untuk memperoleh jarak yang sejauh-jauhnya. Sedangkan menurut Winendra adi (2008:49). Lompat jauh adalah olahraga atletik lompat yang menuntut keterampilan melompat ke depan sejauh mungkin dengan satu kali tolakan. Biasanya, pelompat jauh yang andal juga merupakan pelari jarak pendek yang tangguh. Sebab, penepatan fisik kedua olahraga itu hampir sama, yaitu kaki dan otot perut yang kuat, kecepatan lari jarak pendek, dan hentakan kaki.

Peneliti melakukan observasi ke sekolah-sekolah yang ada di sekolah menengah pertama negeri Kota Bengkulu. Untuk melihat bagaimana penerapan kegiatan ekstrakurikuler yang diterapkan oleh guru atau pelatih ekstrakurikuler atletik tersebut. Sarana dan prasarana yang tersediapun tidak luput dari pengamatan peneliti. Kemudian peneliti melihat juga dari segi kelengkapan sarana dan prasarana serta peran pelatih dan metode latihan sudah dapat di kategorikan baik ataukah belum. Latar belakang ini sendiri peneliti buat berdasarkan observasi.

\section{METODE}

Jenis penelitian ini adalah deskriptif kualitatif. Peneliti menggunakan penelitian deskriptif dengan tujuan untuk mengungkapkan atau menyelidiki suatu keadaan yang sebenarnya. Menurut Arikunto (2006:11) metode penelitian kualitatif dinamakan sebagai metode baru. Karena popularitasnya belum lama, dinamakan metode post positivistic karena berlandaskan pada filsafat post positivisme. Metode ini disebut juga sebagai metode arsistic, karena proses penelitian yang bersifat seni (kurang berpola), dan disebut sebagai metode interpretive karena data hasil penelitian lebih berkenan dengan interpretasi terhadap data yang ditemukan di lapangan. Sehingga dari pendapat ini dapat dikatakan bahwa hasil penelitian ini lebih menekankan makna dari pada generalisasi. Pada penelitian ini peneliti merupakan aspek yang paling penting.

Subjek penelitian merupakan nara sumber, parsipan, informan yang dapat memberikan informasi-informasi yang dibutuhkan dalam penelitan karena tujuan penelitian kualitatif 
adalah untuk menghasilkan teori, (Sugioyo, 2012:216)

Pengambilan subjek dalam penlitian ini menggunakan tehnik purposive, yaitu dengan memilih orangorang yang dianggap tahu tentang focus masalah seperti pihak yang terkait dengan pengambilan keputusan seperti Pembina, pelatih dan siswa ekstrakulikuler atletik nomor lompat jauh di Sekolah Menengah Pertama Negeri kota Bengkulu yang berjumlah 3 Sekolah. Kemudian dipadukan dengan tehnik snowball sampling, yaitu meminta informan sebelumnya tersebut untuk menunjuk orang-orang yang dapat dijadikan informan berikutnya.

Subjek diambil berdasarkan sekolah menengah pertama negeri kota Bengkulu, yang memiliki ekstrakulikuler atletik, serta keterbatasan waktu dan biaya maka peneliti mengambil subjek penelitian antara lain SMP Negeri 02, SMP Negeri 16, SMP Negeri 18 kota Bengkulu.

Penelitian ini menggunakan teknik pengumpulan data berupa kata kata tertulis atau lisan, gambar, foto atau tindakan yang diperoleh dari sumber data, yaitu: orang, tulisan dan tempat. Metode pengumpulan data yang benar akan menghasilkan data yang memiliki kredibilitas tinggi. Ada beberapa metode dalam pengumpulan data kualitatif menurut Suharsimi Arikunto (2010:193).

a. Pengamatan / Observasi

Observasi merupakan suatu kegiatan mendapatkan informasi yang diperlukan untuk menyajikan gambaran riil suatu preristiwa atau kejadian untuk menjawab pertanyaan penelitian, untuk membantu mengerti prilaku manusia dan untuk evaluasi yaitu melakukan pengukuran terhadap aspek tertentu melakukan umpan balik terhadap pengukuran tersebut. Hasil observasi berupa aktifitas, kejadian, pristiwa, objek, kondisi atau suasana tertentu. Dalam hal ini untuk mengetahui dari implementasi ekstrakulikuler atletik nomor lompat jauh di sekolah menengah pertama negeri Kota Bengkulu.

b. Wawancara

Wawancara merupakan proses memperoleh penjelasan untuk mengumpulkan informasi dengan menggunakan cara Tanya jawab bisa sambil bertatap muka ataupun tanpa tatap muka yaitu melalui media telekomunikasi antara pewawancara dengan orang yang diwawancarai, Wawancara merupakan kegiatan untuk memperoleh informasi secara mendalam tentang sebuah isu atau tema yang diangkat dalam penelitian. Hal ini dilakukan untuk menggali informasi yang sebanyak-banyaknya dari informan. Wawancara ditunjukan pada Pembina dan pelatih ekstrakulikuler atletik nomor lompat jauh sekolah menengah pertama negeri kota Bengkulu.

c. Angket atau kuesioner

Angket atau kuesioner merupakan tehnik pengumpulan data yang dilakukan dengan cara memberi sepererangkat pertanyaan atau pernyataan tertulis kepada responden untuk dijawab. Dalam hal ini untuk mengetahui persepsi atau pendapat tentang implementasi / penerapan ekstrakurikuler atletik nomor lompat jauh pada sekolah menengah pertama negeri Kota Bengkulu.

d. Dokumentasi

Dokumentasi merupakan

metode pengumpulan data kualitatif 
sejumlah besar fakta dan data tersimpan dalam bahan yang berbentuk dokumentasi. Sebagian data berbentuk surat, catatan harian, arsip foto, hasil rapat, cendramata, jurnal kegiatan dan sebagainya. Dokumentasi ini untuk memperkuat data yang diperoleh dengan observasi, kuesioner/angket dan wawancara.

\section{HASIL DAN PEMBAHASAN}

Berdasarkan jawaban Angket yang telah dibagikan oleh peneliti kepada para siswa yang mengikuti kegiatan ekstrakurikuler dan terbagi atas 5 kategori dari 20 soal yaitu 4 $(1,2,3,4)$ soal tentang Manajemen ekstrakurikuler atletik, $6(5,6,7,8,9,10)$ soal tentang sarana dan prasarana, 4 $(11,12,13,14)$ soal tentang pelatih yang kompeten, $4(15,16,17,18)$ soal tentang Motivasi, $2(19,20)$ soal tentang prestasi. Dari 20 soal tersebut terdapat juga kuesioner positif dan negative. Sedangkan nilai skala jawaban pada angket ini adalah 5, 4, 3, 2, dan 1 untuk jawaban SS, S, RR, TS, STS dan ini berguna untuk kuesioner positif dan nilai 1, 2, 3, 4, dan 5 untuk jawaban SS, S, RR, TS, STS untuk kuesioner negatif didapatkan hasil sebagai berikut:

Gambar 1. Jawaban Angket SMPN 02 Kota Bengkulu

\begin{tabular}{|c|c|}
\hline \multicolumn{2}{|c|}{$\begin{array}{c}\text { Hasil Kuesioner SMPN } 02 \text { Kota } \\
\text { Bengkulu }\end{array}$} \\
\hline & SMPN 02 Kota Bengkulu \\
\hline 口 Manajemen & $51 \%$ \\
\hline $\begin{array}{l}\text { Sarana dan } \\
\text { Prasarana }\end{array}$ & $53.67 \%$ \\
\hline $\begin{array}{l}\text { Pelatih yang } \\
\text { Kompeten }\end{array}$ & $65.75 \%$ \\
\hline Mntivasi & $6450 \%$ \\
\hline
\end{tabular}

Tabel 1. persentase Rata-rata keseluruhan Kuesioner SMPN 02 Kota Bengkulu

\begin{tabular}{c|c|c} 
No & Variabel & Persentase \\
\hline 1 & Manajemen & $51 \%$ \\
\hline 2 & $\begin{array}{c}\text { Sarana dan } \\
\text { Prasarana }\end{array}$ & $53.67 \%$ \\
\hline 3 & $\begin{array}{c}\text { Pelatih yang } \\
\text { Kompeten }\end{array}$ & $65.75 \%$ \\
\hline 4 & Motivasi & $64.50 \%$ \\
\hline 5 & Prestasi & $33.50 \%$ \\
\hline \multicolumn{2}{|c}{ Total Persentase } & $\mathbf{2 6 8 . 4 2 \%}$ \\
\hline \multicolumn{3}{|c}{ Rata-Rata } \\
Berdasarkan Gambar dan Tabel
\end{tabular}

Persentase kuesioner Sekolah Menengah Pertama Negeri 02 Kota Bengkulu maka dapat dikatakan bahwa Hasil Variabel:

1. Manajemen, berdasarkan hasil pengolahan data tabel 3 Menunjukan bahwa 51\% (Kurang Baik).

2. Sarana dan Prasarana, berdasarkan hasil pengolahan data tabel 3 menunjukan 53,67\% (Kurang Baik).

3. Pelatih yang Kompeten, berdasarkan hasil pengolahan tabel 3 menunjukan 65,75\% (Baik).

4. Motivasi, berdasarkan hasil pengolahan data tabel 3 menunjukan 64,50\% (Baik).

5. Prestasi, berdasarkan hasil pengolahan data tabel 3 menunjukan 33,50\% (Kurang Baik).

Berdasarkan hasil persentase maka total persentase pada sekolah menengah pertama negeri 02 kota Bengkulu adalah $268,42 \%$ dengan persentase rata-rata $53,68 \%$ berada pada klasifikasi $40-60 \%$ dengan kategori Kurang Baik.

Berdasarkan jawaban Angket yang telah dibagikan oleh peneliti kepada para siswa yang mengikuti 
kegiatan ekstrakurikuler dan terbagi atas 5 kategori dari 20 soal yaitu 4 $(1,2,3,4)$ soal tentang Manajemen ekstrakurikuler atletik, $6(5,6,7,8,9,10)$ soal tentang sarana dan prasarana, 4 $(11,12,13,14)$ soal tentang pelatih yang kompeten, $4(15,16,17,18)$ soal tentang Motivasi, $2(19,20)$ soal tentang prestasi. Dari 20 soal tersebut terdapat juga kuesioner positif dan negative. Sedangkan nilai skala jawaban pada angket ini adalah 5, 4, 3, 2, dan 1 untuk jawaban SS, S, RR, TS, STS dan ini berguna untuk kuesioner positif dan nilai 1, 2, 3, 4, dan 5 untuk jawaban SS, $S, R R, T S, S T S$ untuk kuesioner negatif didapatkan hasil sebagai berikut:

Gambar 2. Jawaban Angket SMPN 16 Kota Bengkulu

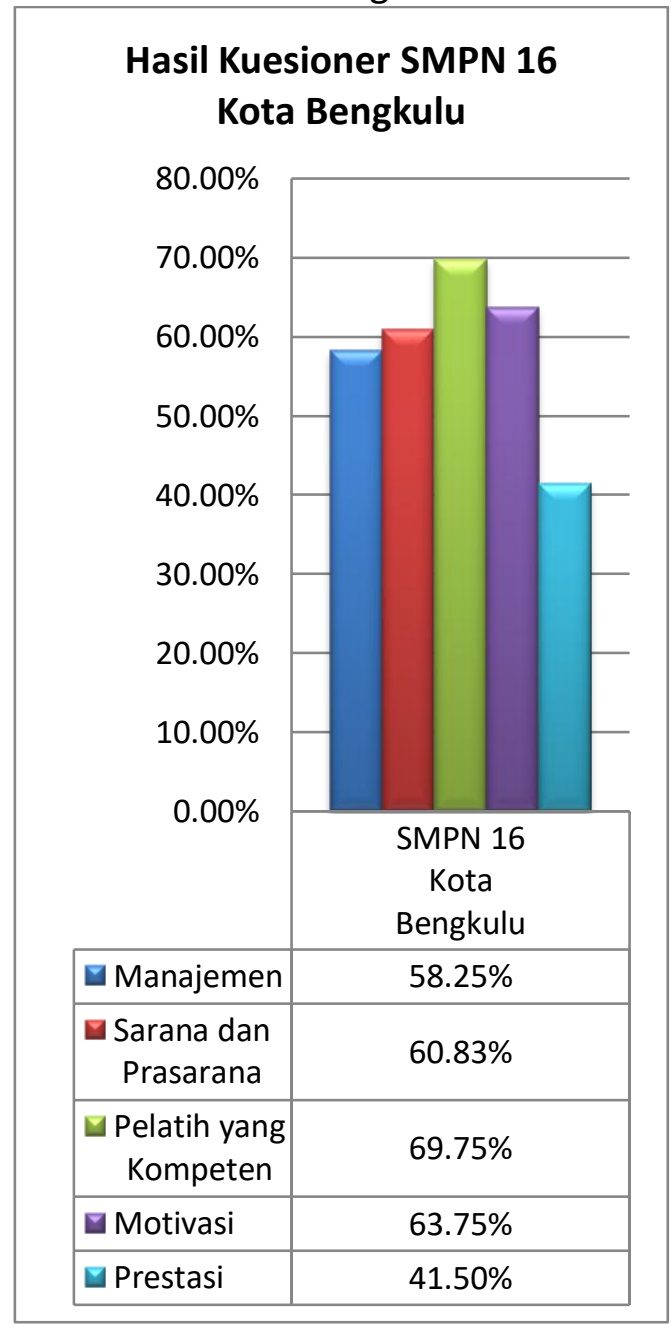

Tabel 2. persentase Rata-rata keseluruhan Kuesioner SMPN 16

Kota Bengkulu

\begin{tabular}{c|c|c} 
No & Variabel & Persentase \\
\hline 1 & Manajemen & $58.25 \%$ \\
\hline 2 & $\begin{array}{c}\text { Sarana dan } \\
\text { Prasarana }\end{array}$ & $60.83 \%$ \\
\hline 3 & $\begin{array}{c}\text { Pelatih yang } \\
\text { Kompeten }\end{array}$ & $69.75 \%$ \\
\hline 4 & Motivasi & $63.75 \%$ \\
\hline 5 & Prestasi & $41.50 \%$ \\
\hline \multicolumn{2}{c|}{ Total Persentase } & $\mathbf{2 9 4 . 0 8 \%}$ \\
\hline \multicolumn{2}{|c}{ Rata-Rata } & $\mathbf{5 8 . 8 1 \%}$
\end{tabular}

Berdasarkan Gambar dan Tabel Persentase kuesioner Sekolah Menengah Pertama Negeri 16 Kota Bengkulu maka dapat dikatakan bahwa Hasil Variabel:

1. Manajemen, berdasarkan hasil pengolahan data tabel 4 menunjukan bahwa 58,25\% (Kurang Baik).

2. Sarana dan Prasarana, berdasarkan hasil pengolahan data tabel 4 menunjukan bahwa $60,83 \%$ (Baik).

3. Pelatih yang Kompeten, berdasarkan hasil pengolahan data tabel 4 menunjukan bahwa 69,75\% (Baik).

4. Motivasi, berdasarkan hasil pengolahan data tabel 4 menunjukan bahwa 63, 75\% (Baik).

5. Prestasi, berdasarkan hasil pengolahan data tabel 4 menunjukan bahwa $41,50 \%$ (Kurang Baik).

Berdasarkan hasil persentase maka total persentase pada sekolah menengah pertama negeri 16 kota Bengkulu adalah 294,08\% dengan persentase rata-rata $58,81 \%$ berada pada klasifikasi 40-60\% dengan kategori Kurang Baik.

Berdasarkan jawaban Angket yang telah dibagikan oleh peneliti 
kepada para siswa yang mengikuti kegiatan ekstrakurikuler dan terbagi atas 5 kategori dari 20 soal yaitu 4 $(1,2,3,4)$ soal tentang Manajemen ekstrakurikuler atletik, $6(5,6,7,8,9,10)$ soal tentang sarana dan prasarana, 4 $(11,12,13,14)$ soal tentang pelatih yang kompeten, $4(15,16,17,18)$ soal tentang Motivasi, $2 \quad(19,20)$ soal tentang prestasi. Dari 20 soal tersebut terdapat juga kuesioner positif dan negative. Sedangkan nilai skala jawaban pada angket ini adalah 5, 4, 3, 2, dan 1 untuk jawaban SS, S, RR, TS, STS dan ini berguna untuk kuesioner positif dan nilai 1, 2, 3, 4, dan 5 untuk jawaban SS, $S, R R, T S, S T S$ untuk kuesioner negatif didapatkan hasil sebagai berikut:

Gambar 3. Jawaban Angket SMPN 18

Kota Bengkulu

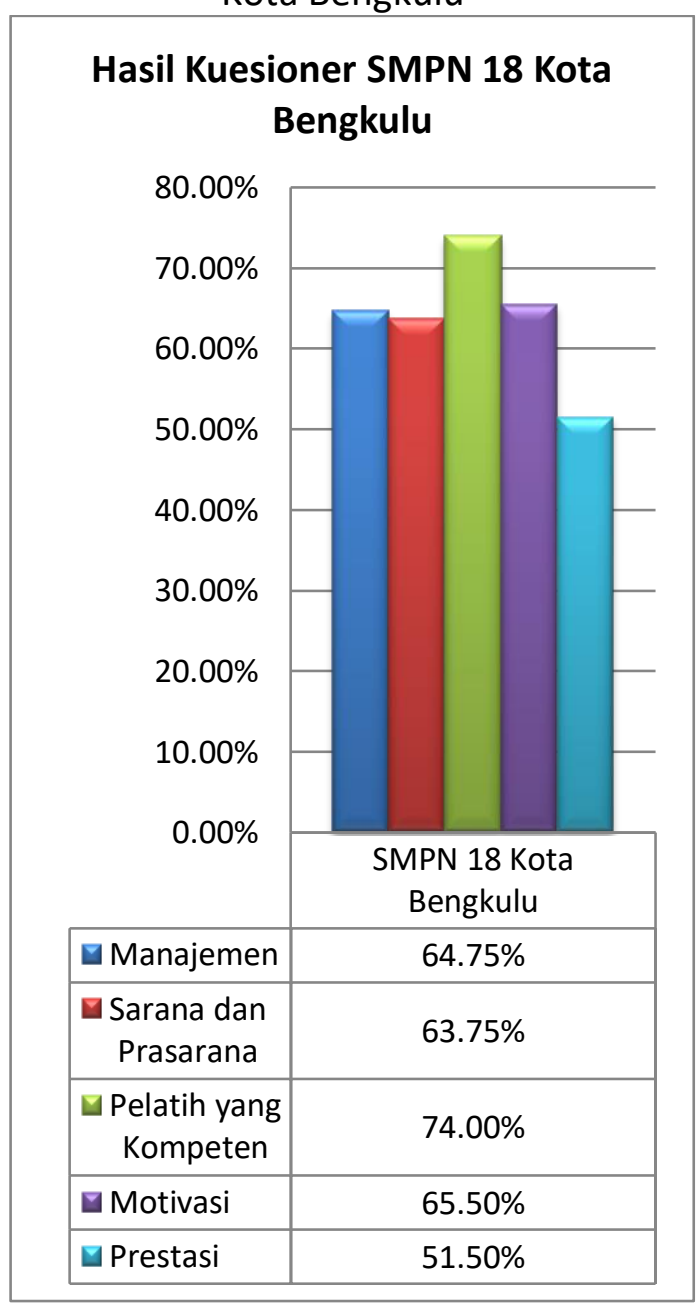

Tabel 3. persentase Rata-rata

keseluruhan Kuesioner SMPN 18

Kota Bengkulu

\begin{tabular}{c|c|c} 
No & Variabel & Persentase \\
\hline 1 & Manajemen & $64.75 \%$ \\
\hline 2 & $\begin{array}{c}\text { Sarana dan } \\
\text { Prasarana }\end{array}$ & $63.75 \%$ \\
\hline 3 & $\begin{array}{c}\text { Pelatih yang } \\
\text { Kompeten }\end{array}$ & $74.00 \%$ \\
\hline 4 & Motivasi & $65.50 \%$ \\
\hline 5 & Prestasi & $51.50 \%$ \\
\hline \multicolumn{2}{|c}{ Total Persentase } & $\mathbf{3 1 9 . 5 \%}$ \\
\hline \multicolumn{2}{|c}{ Rata-Rata } & $\mathbf{6 3 . 9 \%}$
\end{tabular}

Berdasarkan Gambar dan Tabel

Persentase kuesioner Sekolah

Menengah Pertama Negeri 18 Kota

Bengkulu maka dapat dikatakan bahwa Hasil Variabel:

1. Manajemen, berdasarkan hasil pengolahan data tabel 5 menunjukan bahwa $64,75 \%$ (Baik).

2. Sarana dan Prasarana, berdasarkan hasil pengolahan data tabel 5 menunjukan bahwa 63,75\% (Baik).

3. Pelatih yang Kompeten, berdasarkan hasil pengolahan data tabel 5 menunjukan bahwa 74,00\% (Baik).

4. Motivasi, berdasarkan hasil pengolahan data tabel 5 menunjukan bahwa $65,50 \%$ (Baik).

5. Prestasi, berdasarkan hasil pengolahan data tabel 5 menunjukan bahwa 51,50\% (Kurang Baik).

Berdasarkan hasil persentase maka total persentase pada sekolah menengah pertama negeri 18 kota Bengkulu adalah $319,5 \%$ dengan persentase rata-rata $63,9 \%$ berada pada klasifikasi 60-80\% dengan kategori Baik.

Jadi, hasil kuesioner siswa Sekolah Menengah Pertama Negeri Kota Bengkulu adalah 58\% untuk 
Kategori Manajemen, 59,41\% untuk kategori Sarana dan Prasarana, 70.03\% untuk kategori pelatih yang kompeten, 64.58\% untuk kategori Motivasi, 42.2\% untuk Kategori Prestasi. Dan dari kategori diatas memiliki rata-rata persentase sebesar $58,84 \%$. Yang mana persentase $58,84 \%$ berada pada Klasifikasi Kurang Baik Yang memiliki rentang nilai persentase antara 40 $60 \%$. Hasil ini membuktikan bahwa implementasi ekstrakurikuler atletik nomor lompat jauh pada Sekolah Menengah Pertama Negeri Kota Bengkulu belum Maksimal.

\section{PEMBAHASAN}

Berdasarkan hasil penelitian yang diperoleh bahwa pembahasan mengenai implementasi ekstrakurikuler atletik nomor lompat jauh pada Sekolah Menengah Pertama Negeri Kota Bengkulu adalah Sebagai Berikut:

$$
\text { Manajemen ektrakurikuler }
$$
atletik nomor lompat jauh dapat dikatakan maksimal apabila komponen - komponen yang terdiri dari pengelolaan ekstrakurikuler, Sumber pelatih yang jelas. Ini semua akan tetap berjalan meskipun mengalami beberapa kendala pada saat sulitnya mengatur manajemen yang baik dalam pengelolaannya.

Pengelolaan ekstrakurikuler atletik pada sekolah menengah pertama negeri kota Bengkulu ratarata di kelola oleh sekolah masingmasing. Dan tidak semua sekolah memiliki ekstrakurikuler atletik. Karna tercatat hanya sekolah-sekolah yang mempunyai kelas olahraga yang memiliki ekstrakurikuler atletik. Adapun sumber pelatih, tercatat hanya ada satu sekolah dari tiga sekolah yang memiliki pelatih yang bersetifikat dan hanya satu sekolah saja yang memiliki pelatih di luar sekolah. Sumber peserta ekstrakurikuler dipilih ketika dia masuk pendaftar ke sekolah menengah pertama melalui jalur tes kelas olahraga. Yang mana tes tersebut disesuaikan dengan nomor cabang olahraga setiap siswa. Dan sumber siswa ekstrakurikuler atletik di sekolah menengah pertama negeri kota Bengkulu juga diambil dari kelas regular yang mana sumber peserta ini diambil dari minat serta bakat siswa yang bersangkutan. Selain itu,upaya untuk menjaring siswa yang berbakat dalam ekstrakurikuler atletik nomor lompat jauh di sekolah menengah pertama kota Bengkulu dapat dilakukan melalui kegiatan pembelajaran olahraga. Pembina atau pelatih dapat melihat bakat yang dimiliki siswa dalam olahraga atletik nomor lompat jauh. Tentunya berdasarkan kriteria siswa berbakat yang akan dijadikan bibit unggul sebagai siswa ekstrakurikuler atletik nomor lompat jauh. Misalnya bawaan bakat sejak lahir, kondisi fisik dan mental yang sehat, bentuk tubuh yang bagus, kegemaran dalam berolahraga dan lain-lain.

Selain manajemen, sarana dan prasarana adalah hal yang jangan disepelehkan karna sarana dan prasara adalah penunjang dalam berlatih sehingga siswa ekstrakurikuler atletik nomor lompat jauh bisa berprestasi. Yang mana keadaan sarana dan prasarana yang ada dalam menunjang ekstrakurikuler atletik terkesan seadanya. Dan terlihat sarana dan prasarana yang ada hanya disiapkan sebagai penunjang belajar saja. Selain itu kualitas dari sarana prasarana khususnya lompat jauh masih terkesan kurang perhatian dari pihak sekolah, begitupun ukurannya yang masih butuh 
perhatian khusus dalam penerapan ekstrakurikuler atletik yang baik. Untuk prasarana ekstrakurikuler atletik nomor lompat jauh terbilang cukup baik. Karena rata-rata sekolah yang menerapkan ekstrakurikuler atletik nomor lompat jauh di sekolah menengah pertama negeri kota Bengkulu memiliki prasarana yang cukup baik.

Pelatih yang kompeten merupakan unsure yang sangat penting karena tanpa pelatih yang baik, akan membuat prestasi tidak maksimal, dari beberapa sekolah yang di teliti hanya ada satu sekolah memiliki pelatih yang berlisensi pelatih atletik selain itu dari beberapa sekolah yang diteliti hanya ada satu sekolah juga yang memiliki pelatih dari luar sekolah. Adapun untuk program latihan, yang mana ekstrakurikuler atletik nomor lompat jauh di sekolah menengah pertama negeri kota Bengkulu memiliki program latihan yang tertulis dan berkala dalam berlatih. Serta sebelum latihan pelatih mengintruksikan peserta ekstrakurikuler melakukan pemanasan umum, serta melakukan pemanasan khusus atletik sebelum memasuki program latihan ini. Selain itu peserta ekstrakurikuler atletik nomor lompat jauh juga melakukan pendinginan sesudah latihan.

Motivasi merupakan salah satu penunjuang secara mental dalam berlatih agar terpacuhnya siswa dalam meraih prestasi dan berlatih, banyak faktor dalam pencapaian prestasi di sekolah menengah pertama kota Bengkulu. Mulai dari pihak sekolah, Pembina, pelatih, maupun siswa ekstrakurikuler serta adanya sarana dan prasarana yang baik Sebagai penunjang prestasi.
Prestasi yang diraih oleh ekstrakurikuler atletik nomor lompat jauh dominan masih rendah, hal ini dikarenakan pengelolaan yang belum maksimal dan jarang sekali diadakan event atletik untuk tingkat sekolah menengah pertama. Apabila siswa ekstrakurikuler atletik meraih prestasi tentunya pihak sekolah akan memberikan penghargaan tetapi tidak dalam bentuk materi melaikan hanya pujian-pujian dan memotivasi untuk siswa agar lebih giat dalam berlatih mencapai prestasi.

Berdasarkan hasil kuesioner siswa Sekolah Menengah Pertama Negeri Kota Bengkulu yang terdiri dari 5 kategori yaitu Manajemen, Sarana dan Prasarana, Pelatih yang Kompeten, Motivasi dan prestasi adapun hasil persentase dari kelima kategori tersebut adalah untuk Kategori Manajemen sebesar 58\% Klasifikasi kurang baik, Sarana dan Prasarana 59,41\% Klasifikasi kurang baik, untuk pelatih yang kompeten sebesar 70,03\% Klasifikasi baik, untuk Kategori Motivasi 64,58\% Klasifikasi Baik, untuk Kategori Prestasi 42,2\% dengan klasifikasi kurang baik. Dan dari kategori diatas memiliki rata-rata persentase sebesar $58,84 \%$. Yang mana persentase $58,84 \%$ berada pada Klasifikasi Kurang Baik Yang memiliki rentang nilai persentase antara $40-60 \%$. Hasil ini membuktikan bahwa implementasi ekstrakurikuler atletik nomor lompat jauh pada Sekolah Menengah Pertama Negeri Kota Bengkulu belum Maksimal.

\section{PENUTUP}

\section{SIMPULAN DAN SARAN}

Berdasarkan hasil kuesioner siswa Sekolah Menengah Pertama Negeri Kota Bengkulu yang terdiri dari 5 
kategori yaitu Manajemen, Sarana dan Prasarana, Pelatih yang Kompeten, Motivasi dan prestasi adapun hasil persentase dari kelima kategori tersebut adalah untuk Kategori Manajemen sebesar 58\% Klasifikasi kurang baik, Sarana dan Prasarana $59,41 \%$ Klasifikasi kurang baik, untuk pelatih yang kompeten sebesar $70,03 \%$ Klasifikasi baik, untuk Kategori Motivasi 64,58\% Klasifikasi Baik, untuk Kategori Prestasi 42,2\% dengan klasifikasi kurang baik. Dan dari kategori diatas memiliki rata-rata persentase sebesar $58,84 \%$. Yang mana persentase $58,84 \%$ berada pada Klasifikasi Kurang Baik Yang memiliki rentang nilai persentase antara $40-60 \%$. Hasil ini membuktikan bahwa implementasi ekstrakurikuler atletik nomor lompat jauh pada Sekolah Menengah Pertama Negeri Kota Bengkulu belum Maksimal.

1. Adapun saran dari penelitian ini adalah sebagai berikut : Kepada Pembina dan pelatih, perlu mengambil suatu langkah pengelolaan keseluruhan terhadap ekstrakurikuler atletik nomor lompat jauh, agar siswa tetap berlatih secara terus menerus dan hendaknya menambah sarana untuk latihan sehingga keaktifan siswa dalam latihan meningkat karena pembinaan yang baik adalah pembinaan yang dilakukan melalui latihan yang rutin untuk mencapai prestasi yang maksimal.

2. Kepala Pembina, Pelatih dan pihak sekolah untuk menata manajemen yang lebih baik lagi agar keberadaan ekstrakurikuler atletik di sekolah menengah pertama negeri kota Bengkulu ini mendapat perhatian dan dukungan dari pemerintah Kota Bengkulu, sehingga masalah dana dan fasilitas dapat teratasi.

3. Kepada siswa harus disiplin, selalu belajar dan berlatih dengan sungguh-sungguh agar dapat mencapai prestasi maksimal.

4. Kepada Program Studi S-1 Penjas Universitas Bengkulu hendaknya bekerjasama dengan pihak terkait seperti DISPORA dan PASI serta pihak sekolah untuk membangkitkan kembali ekstrakurikuler atletik dengan lebih banyak mengadakan event atletik untuk tingkat sekolah menengah pertama sehingga dalam penerapan ekstrakurikulet atletik nomor lompat jauh ini memiliki target untuk berprestasi.

5. Kepada orang tua dan masyarakat untuk senantiasa memberikan motivasi dan respon yang baik terhadap penerapan ekstrakurikuler atletik nomor lompat jauh pada sekolah menengah pertama negeri KotaBengkulu.

\section{DAFTAR PUSTAKA}

Adi, Winendra. 2008. Seri Olahraga Atletik. Yogyakarta: Insan Madani

Arikunto, Suharmi. 2004. Prosedur penelitian suatu pendekatan praktik, Jakarta: Renika Cipta.

Arsil. 2010. Evaluasi Pendidikan Jasmani dan Olahraga. Padang: Wineka Media.

Djumidar. 2005. Dasar-Dasar Atletik. Jakarta: Universitas Terbuka.

Gade, Fithriani. 2014. Implementasi metode takrar dalam pembelajaran menghafal alquran. Jurnal Ilmiah. Aceh: 
Fakultas Tarbiyah dan Keguruan UIN Ar-Raniry.

Hanggara, deri. 2017. "implementasi ekstrakulikuler bola voli di sma negeri Bengkulu tengah". Skripsi. Bengkulu: Fakultas Keguruan dan Ilmu Pendidikan. Universitas Bengkulu.

Hasan, Mohammad. 2010. Peraturan perlombaan. Jakarta: PASI

Kompri. 2015. Manajemen Pendidikan.Yogykarta: ARRUZZ MEDIA

Mane, fred Mc. 2000. Dasar-Dasar Atletik. Bandung: Angkasa Bandung.

Pitria, Tono, dan Arwin. 2019. "Perbedaan Pengaruh Latihan Pliometrik Single Leg Speed Hop dan Double Leg Speed Hop Terhadap Kemampuan Lompat Jauh Gaya Jongkok
Di SMA Negeri 08 Bengkulu Utara".Jurnal Kinestetik, Vol. $3(1)$

Pujianto, Dian dan Bayu insanistyo. (2013). Dasar-dasar penelitian pendidikan jasmani. Bengkulu: FKIP Universitas Bengkulu.

Riski Pitalokia, Septi. 2017. "implementasi pembinaan klub bola voli usia dini di sekolah dasar kota Bengkulu”. Skripsi, Bengkulu: Fakultas Keguruan dan Ilmu Pendidikan, Universitas Bengkulu.

Sugiono. 2006. Metode Penelitian Kuantitatif kualitatif dan $R$ dan D.Bandung: Alfabeta Bandung.

Wiarto, Giri. 2013. Atletik. Yogyakarta: Graha Ilmu. 